\title{
REPRODUCTIVE BIOLOGY OF ANCHOVIES (Encrasicholina heterolobus AND Encrasicholina devisi) FROM BACAN, MALUKU
}

\author{
Retno Andamari" and David Milton**,
}

\begin{abstract}
ABSTRAC'T
The reproductive biology of the anchovies, Encrasicholina heterolobus and E. devisi at Bacan were compared with published data from other parts of their geographic range. Sampling was carried out in April. September and November 1996 and April and July 1997. The length. weight relationship for both species has a $b$ value greater than 3 suggesting that the environment is favourable for these species. Both species are multiple spawners and the batch fecun. dity ranged between 1573 and 7090 for E. heterolobus and up to 6959 for $E$. devisi. This is much higher than recorded elsewhere for these species, but is partly due to larger fish size. Age at first spawning varied from 111 to 180 days for E. heterolobus, which is later than that estimated for fish from sites in the Solomon Islands. The age of $E$. devisi at first spawning varied between 81 and 106 days and was less than that found in the Solomon Islands. Both species live longer at Bacan than in the Solomon Islands and so the reproductive life span is also longer than found elsewhere. This means that the lifetime egg production of $E$. heterolobus and $E$. devisi at Bacan is higher than in the Solomon Islands. It suggests that populations of $E$. heterolobus and $E$. devisi in Bacan should be able to sustain higher long-term exploitation and be able to recover more rapidly from short periods of overexploitation.
\end{abstract}

KEYWORDS: tropical anchovies, length-weight, fecundity, age at first spawning, sustainability

\section{INTRODUCTION}

The anchovies. Encrasicholina and Stolephorus species, play an important role as live-bait fish for the skipjack tuna Katsuwonus pelamis fisheries in Maluku. In Bacan and elsewhere in Maluku Province, these anchovies are caught using "bagan" (light-fishing), "redi" (beach seine) and "bouke-ami" (the stick-held dipnet) at night. An understanding of the reproduction of these anchovies is important for determining the sus. tainability of the baitfish supply to the fishery. Previous research has been conducted elsewhere on the reproductive biology of the stolephorid anchovies (Sumadhiharga. 1995: Milton et al. 1990; Milton et al.1995).

The present study was carried out in Bacan, north Maluku and the objectives were: (1) to determine length-weight relationships, batch fecundity, age at first spawning, and egg production of Encrasicholina heterolobus and Encrasicholina devisi at Bacan: and (2) to compare the results with other studies from the tropical Pacific in order to assess the relative sustainability of the Bacan anchovy populations.

\section{MATERIALS AND METHODS}

\section{Sampling}

Random sub-samples of $E$. heterolobus and $E$. devisi were collected from bagans in the main baitgrounds at Bacan in. September and November 1996 and April and July 1997. During each sampling trip, 200 fish were collected from at least two bagans each night for at least three consecu. tive nights. All samples were preserved in $10 \%$ formalin and taken back to the laboratory in Ambon for analysis.

\section{Laboratory Analyses}

Fish were measured (standard length $\mathrm{mm}$ ), weighed $( \pm 0.001 \mathrm{~g})$ and then dissected. Gonads were removed and sex and gonad weights were recorded for all of the samples. Gonads were ex.

\footnotetext{
* Ambon Assessment Institute for Agricultural Technology, Agency for Agriculture

Research and Development. Ministry of Agriculture, Indonesia.

* CSIRO Marine Research. PO Box 120, Cleveland, Qld. 4163, Australia
} 
amined histologically to identify their stage of development (Andamari et al., this issue). Fish that had ripe eggs (> Stage 4 of Milton and Blaber. 1991) were used to estimate fecundity.

Batch fecundity was estimated by weighing a sub-sample of gonad and counting the number of eggs (Bagenal. 1978) and batch fecundity was estimated from the equation:

$$
F=(W g / W s) \cdot n
$$

where $F=$ batch fecundity

$W g=\operatorname{gonad}$ weight $(\mathrm{g})$

$W s=$ weight gonad of sub sample $(\mathrm{g})$

$n$ = number of eggs in sub sample

Fish were given an estimated age based on the growth equation of Wright (1989) for E. heterolobus in Java and by counting daily growth rings of $E$. devisi. The age at first spawning was estimated from the age of fish with mature gonads. Age at sexual maturity was defined as the age at which fish first developed ripe eggs (Stage 4). This occurred at 83 days for E. heterolobus and 63 days for $E$. devisi. The reproductive life span for each species on each day was estimated by subtracting the age at maturity from the estimated age of the largest fish. Lifetime egg production was estimated by the method of Milton et al. (1995) and was the product of length-specific fecundity and days between spawning.

\section{RESULTS AND DISCUSSION}

A summary of the length and weight of the samples collected is given in Table 1 . The lengthweight relationships are shown in Table 2 . The value of $b$ in Bacan of each species was compared with other sites. In Bacan. it was always greater than 3, which means that the fish grow allometrically.

The batch and relative fecundity of E. heterolobus and E. devisi differed between trips. The batch fecundities of $E$. heterolobus and $E$. devisi in Bacan are higher than at other sites except for Ambon Bay (Table 3). The fecundity of E. heterolobus was much lower in July 1997 compared with other sampling periods. The single estimate of fecundity of E. devisi in September 1996 was higher than at other sites in the Solomon Islands or Papua New Guinea.

The age at first spawning and reproductive life span of $E$. heterolobus and $E$. devisi varied between sampling periods (Table 4). In Bacan, female $E$. heterolobus were older at first spawning than $E$. devisi, and older than those estimated in the Solomon Islands. In contrast, E. devisi spawned first at a younger age than in the Solomon Islands. The mean reproductive life span of $E$. heterolobus varied from 27 to 97 days, and from 18 days to 43 days for $E$. devisi. In the Solomon Islands, the mean reproductive life span of $E$. devisi was longer than in Bacan.

These results have implications for the sustainability of anchovies in Bacan. Mean total lifetime egg production of $E$. heterolobus was 3 to 20 times that estimated for Solomon Islands fish. The total egg production of $E$. devisi also appears to be higher, but the difference is not as great. The higher fecundity of female anchovies in Bacan indicates that these species are more likely to be resilient to higher levels of exploitation at Bacan than in the Solomon Islands. The larger mean

Table 1. The mean and range in length $(\mathrm{mm})$ and weight $(\mathrm{g})$ of anchovies collected from Bacan between September 1996 and July 1997.

\begin{tabular}{|c|c|c|c|c|c|c|c|c|}
\hline \multirow{2}{*}{ Date } & \multirow{2}{*}{ Species } & \multicolumn{3}{|c|}{ Length (mm) } & \multicolumn{3}{|c|}{ Weight (g) } & \multirow{2}{*}{$\mathbf{n}$} \\
\hline & & $\min$ & $\max$ & mean $\pm S E$ & $\min$ & $\max$ & ean $\pm S$ & \\
\hline \multirow[t]{2}{*}{ Sep. 96} & E. heterolobus & 54 & 88 & $73.6 \pm 0.5$ & 1.17 & 6.63 & $3.7 \pm 0.08$ & 230 \\
\hline & E. devisi & 38 & 76 & $59.5 \pm 0.03$ & 0.56 & 4.98 & $2.2 \pm 0.04$ & 412 \\
\hline Nov. 96 & E. heterolobus & 30 & 93 & $73.7 \pm 0.5$ & 0.19 & 8.83 & $4.4 \pm 0.08$ & 434 \\
\hline Apr. 97 & E. heterolobus & 49 & 86 & $69.3 \pm 0.2$ & 0.78 & 5.91 & $3.1 \pm 0.02$ & 1,391 \\
\hline \multirow[t]{2}{*}{ Jul. 97} & E. heterolobus & 46 & 94 & $75.9 \pm 0.2$ & 0.75 & 6.85 & $3.7 \pm 0.03$ & 1.107 \\
\hline & E. devisi & 55 & 82 & $67.8 \pm 0.2$ & 1.26 & 5.0 & $2.7 \pm 0.03$ & 496 \\
\hline
\end{tabular}


Table 2. Length-weight relationship of anchovies from Bacan and other areas in the Indo-Pacific region. Equation is of the form $\mathrm{W}=\mathrm{aL}$.

\begin{tabular}{|c|c|c|c|c|c|c|}
\hline Sites & Date & Species & $\mathbf{A}$ & b & $\mathbf{r}^{2}$ & $\mathbf{n}$ \\
\hline \multirow[t]{6}{*}{ Bacan } & Sep-96 & E. heterolobus & $5.4 \times 10^{-. i}$ & 3.38 & 0.95 & 230 \\
\hline & & E. devisi & $8.1 \times 10^{-6 i}$ & 3.29 & 0.95 & 412 \\
\hline & November 1996 & E. heterolobus & $5.4 \times 10^{-6}$ & 3.36 & 0.97 & 434 \\
\hline & Apr -97 & E. heterolobus & $1.6 \times 10^{-5}$ & 3.09 & 0.85 & 1391 \\
\hline & July 1997 & E. heterolobus & $1.6 \times 10^{-5}$ & 3.08 & 0.9 & 1107 \\
\hline & & E. devisi & $1.3 \times 10^{5}$ & 3.11 & 0.85 & 496 \\
\hline Munda' & $1987-1989$ & E. heterolobus & $1.9 \times 10^{-5}$ & 2.82 & 0.79 & 3419 \\
\hline Vona Vona' & $1987-1989$ & E. heterolobus & $8.4 \times 10^{.5}$ & 2.46 & 0.74 & 2465 \\
\hline 'Tulagi' & $1987-1989$ & E. heterolobus & $6.4 \times 10^{5.5}$ & 2.50 & 0.69 & 2400 \\
\hline Munda' & $1987-1989$ & E. devisi & $3.2 \times 10^{.5}$ & 2.71 & 0.70 & 2870 \\
\hline Vona Vona' & $1987-1989$ & E. devisi & $2.2 \times 10^{-5}$ & 2.22 & 0.54 & 3643 \\
\hline Tulagi' & $1987-1989$ & E. devisi & $2.5 \times 10^{5}$ & 2.78 & 0.73 & 2922 \\
\hline \multirow[t]{2}{*}{ Ambon bay ${ }^{2}$} & 1992 & E. heterolobus & $7.9 \times 10^{.5}$ & 2.97 & 0.96 & 700 \\
\hline & 1992 & E. devisi & $8.3 \times 10^{.6}$ & 3.44 & 0.94 & 500 \\
\hline Maldives ${ }^{3}$ & $1987-1989$ & E. heterolobus & $2.1 \times 10^{-6 i}$ & 3.36 & 0.92 & 1289 \\
\hline Ysabel, PNG' & 1982 & E. heterolobus & $2.4 \times 10^{-6 i}$ & 3.35 & 0.98 & 737 \\
\hline Singapore & & E. heterolobus & $3.7 \times 10^{-6}$ & 3.59 & $\cdot$ & - \\
\hline Palau ${ }^{6}$ & 1976 & E. heterolobus & $7.6 \times 10^{-6}$ & 3.09 & . & - \\
\hline New Caledonia $^{7}$ & 1986 & E. heterolobus & $1.2 \times 10^{.6 i}$ & 3.38 & 0.99 & 140 \\
\hline
\end{tabular}

Milton ot al. (1!9!5), "Sumadhiharga (199!5). "Milton ret al. (19990), 'Dal\%ell (1!85), "Tham (1!)66), "s

Muller (1!76). Conand (1!188)

size at Bacan also indicates that the populations are probably not heavily exploited at present. Allometric growth in weight with length suggests that Bacan is a favourable environment for anchovies with plenty of food available. The combination of these population characteristics suggests that anchovy populations in Bacan should be able to sustain higher long-term levels of exploitation than anchovies in the Solomon Islands and be more resilient to short-term over-exploitation or poor recruitment.

\section{Acknowledgements}

We thank Mr. M. Syarif for helping collect the fish samples and Andriko Noto Susanto for laboratory analysis and entering the data. This work was part of the ACIAR-funded Baitfish Research Project and involved collaboration between Research Institute for Marine Fisheries, Agency of Agricultural Research and Development, Minis- try of Agriculture. Indonesia and CSIRO Marine Research. Cleveland. Australia.

\section{REFERENCES}

Bagenal. T.B. 1978. Methods for Assessment of Fish Production in Fresh Water. IBP. Handbook (3) Blackwell Scientific Publications, Oxford. 253 pp.

Conand, F. 1988. Biology and Ecology of Small Pelagic Fish from the Lagoon of New Caledonia Usable as Bait for Tuna Fishing. PhD Thesis, ORSTOM Paris.

Dalzell, P. 1985. Some aspects of the reproductive biology of Spratelloides gracilis in the Ysabel Passage, Papua New Guinea. J. Fish Biol. 27: 229-237.

Dalzell, P. 1987. Some aspects of the reproductive biology of stolephorid anchovies from northern New Guinea. Asian Fish. Sci. 1: 91-106.

Milton. D.A. 1992. Ecology of Five Species of Clupeoid Used as Tuna Baitfish in the Solomon. Islands. $\mathrm{Ph}$ D Thesis. University of Queensland. Brisbane. 145 pp. 


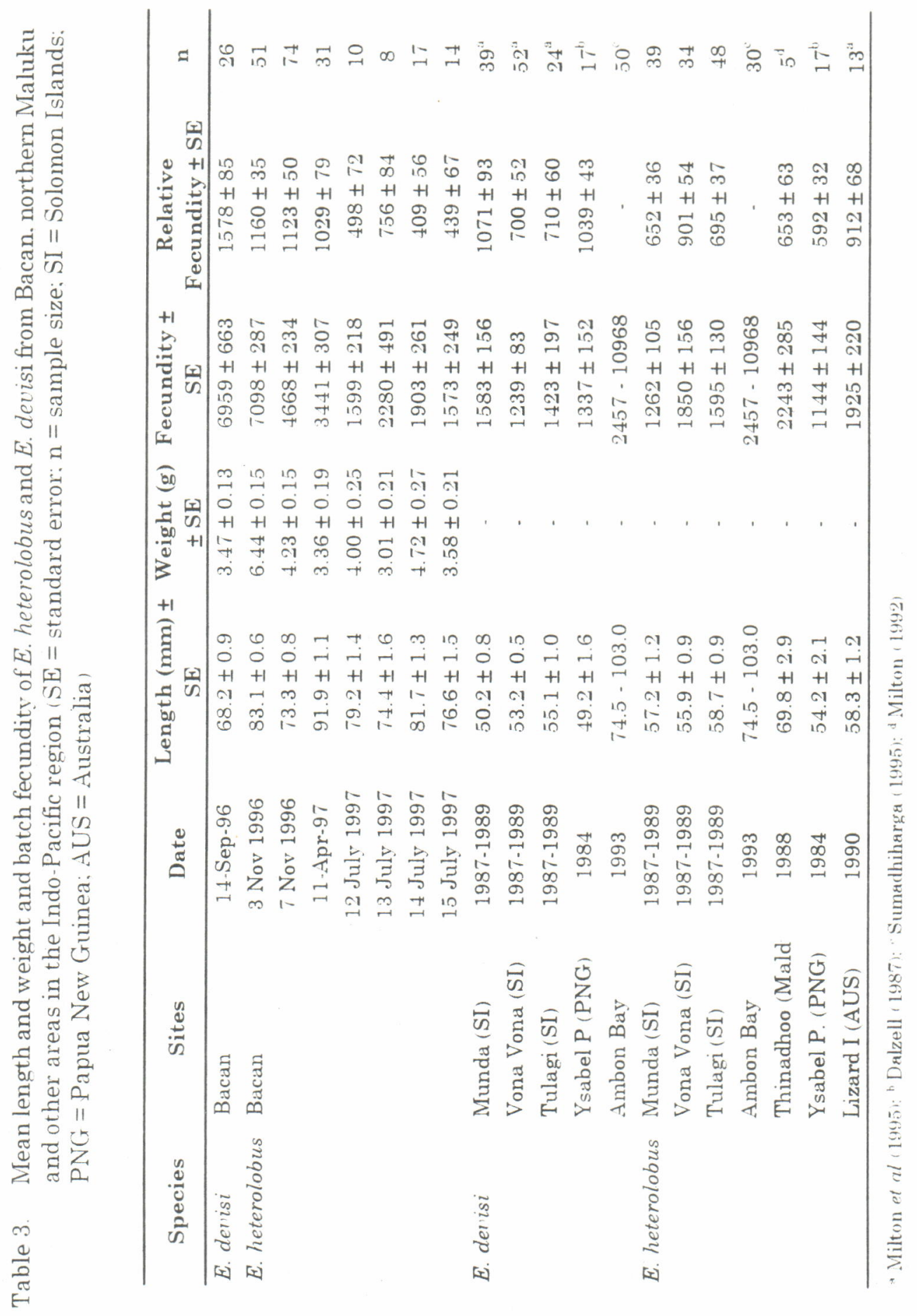




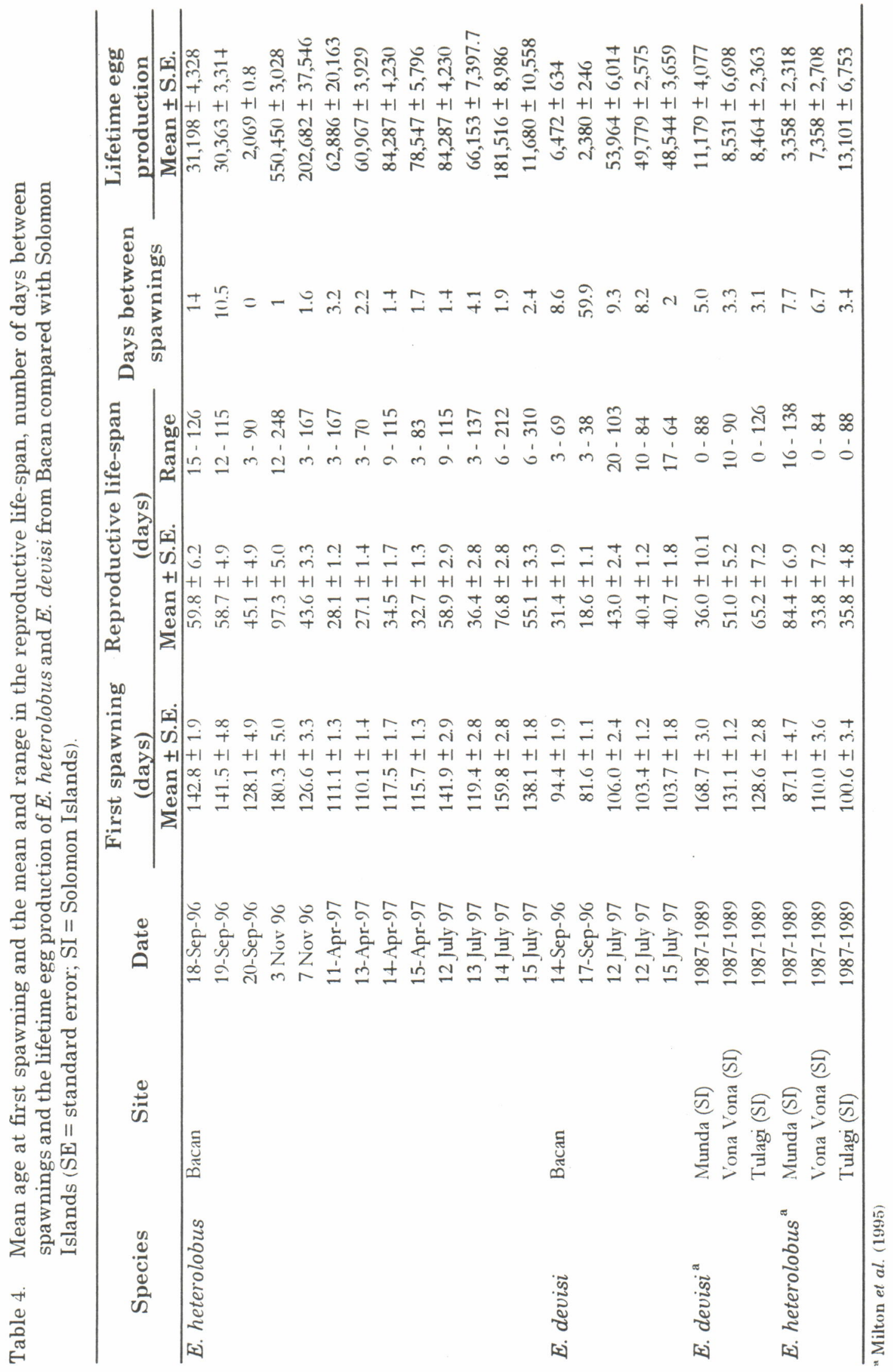


Milton, D.A., Blaber, S.J.M., Tiroba, G., Leqata. J.L.. Rawlinson, N.J.F. and Hafiz, A. 1990. Reproductive biology of Spratelloides delicatulus, S. gracilis and Stolephorus heterolobus from Solomon Islands and Maldives. In Blaber, S.J.M. and Copland, J.W. (eds.). Tuna Baitfish in the Indo-Parific Region. ACIAR Proceedings 30: 89-99.

Milton, D.A., Blaber. S.J.M. and Rawlinson. N.J.F. 1995. Fecundity and egg production of four species of short-lived clupeoid from Solomon Islands, tropical South Pacific. ICES J. Mar. Sci. 52: 111-125.

Muller, R.S. 1976. Population Biology of Stolephorus heterolobus (Pisces: Engraulidae) in Palau, West ern Carolines. PhD Thesis, University of Hawaii. $174 \mathrm{pp}$.
Royce. W.F. 1984. Introduction to the Practice of Fishry Srience. Academic Press, California, USA. 423 pp.

Sumadhiharga, O.K. 1995. Anchovy Fisheries and Ecology with Special Reference to the Reproductive Biol. ogy of Stolephorus spp. in Ambon Bay, Indonesia $\mathrm{Ph}$ D Thesis. University of Tokyo, Japan. 143 pp.

Tham, A.K. 1966. A contribution to a study of the growth of members of the genus Stolephorus in Singapore Strait. Proceeding of the Indo-Pacific Fish. Council 12: 1-25.

Wright, P.J. 1989. The Growth and Reproductive Biol. ogy of Stolephorus heterolobus (Engraulididae). M. Phil Thesis. University of Newcastle upon Tyne.112 pp. 